\title{
Service Encounter Condition, Service Quality and Frontline Employees' Role in Higher Education
}

\author{
Taufani C. Kurniatun \\ taufani@upi.edu
}

can create confidence in the FLE; i.e. operational capability factor (operational competencies), willingness to help consumers factor (service benevolence) and FLE orientation in solving problems (problem solving). On the other hand, FLE is a differentiation source and competitive advantage for the organization and also play a key role in anticipating the needs of consumers, adjusting service delivery and build a personal rapport [5]; [6].

Many of the activities were not running and functioning properly (dysfunction) caused by the behavior of employees in making contact with the customers (FLE/CCE) by making a deviant activity. As a result of this, the organization could have a disadvantage, in terms of both financial and nonfinancial, such as the decline in consumers' perception of the service performance; which leads to the dissatisfaction on the organization, loosing trust and service encounter very susceptible to interference due to the dysfunction services. This is in line with the opinion that the most common service failures indicated with the customer's interactional failure; i.e. a failure caused by something that happened by the time the frontline employee treating customers (like coarse, not paying attention or hostile and the behavior in which identified as a service sabotage [7] and [8].

Thus, the FLE role in the process of service encounter allegedly considered very important in the achievement of service performance. This research will be disclosed further on how the administrative service encounter affects the service quality. This study is considered to be important due to the fact that it is in line with the demands of college prospects; which constantly strive to provide optimal service not only in academics but also in the administrative field.

\section{RESEARCH METHODOLOGY}

University's frontline employees (FLE) in this research was directed at these following four aspects: 1) the types service encounter administrative, 2) FLE qualification, 3) service recovery program, 4) Level of Service Quality

This study used Explanatory Survey Method. Sample research conducted on college students in West Java; which consists of In general, the administrative services at four universities, namely the State University of Non-Owned Legal Entity (BHMN), State Universities Owned Legal Entity (BHMN), Accredited and Non-Accredited Private Universities (PTS) showed no significant difference. The performances of service delivery in all four types of universities were shown quite good range, especially in the aspect of new admissions selection, college preparation, lectures and exams. An important finding of this study was those universities have not 
shown the optimal performance of the services delivery, especially in the aspect of administrative employees' service attitude. In general, the attitude of the employees by the time of doing contact was still far from adequate.

\section{Service Encounter Condition}

III. RESULT AND DISCUSSION

According to the research service encounter conditions when providing the administrative services type can be seen in Table 1.

Table. 1 Service Encounter Condition (SE)

\begin{tabular}{|c|c|c|c|c|}
\hline \multirow[t]{2}{*}{ Service Type } & \multicolumn{3}{|c|}{ Service Encounter Performance Category } & \multirow[b]{2}{*}{$\begin{array}{c}\text { Non-Accredited } \\
\text { Private Universities }\end{array}$} \\
\hline & $\begin{array}{c}\text { State University } \\
\text { Owned Legal Entity }\end{array}$ & $\begin{array}{l}\text { State University Non- } \\
\text { Owned Legal Entity }\end{array}$ & $\begin{array}{c}\text { Accredited Private } \\
\text { Universities }\end{array}$ & \\
\hline $\begin{array}{ll}\text { Admissions Selection } \\
- & \text { Information Submission } \\
- & \text { Selection Schedule } \\
- & \text { Form Reversion }\end{array}$ & $\begin{array}{l}\text { Fairly Good } \\
\text { Fairly Good } \\
\text { Fairly Good } \\
\text { Fairly Good } \\
\end{array}$ & $\begin{array}{l}\text { Fairly Good } \\
\text { Fairly Good } \\
\text { Fairly Good } \\
\text { Fairly Good }\end{array}$ & $\begin{array}{l}\text { Fairly Good } \\
\text { Fairly Good } \\
\text { Fairly Good } \\
\text { Fairly Good }\end{array}$ & $\begin{array}{l}\text { Fairly Good } \\
\text { Fairly Good } \\
\text { Fairly Good } \\
\text { Dissatisfactory }\end{array}$ \\
\hline $\begin{array}{ll}\text { Class } & \text { Preparation } \\
- & \text { Registration } \\
- & \text { Returning a study plan card } \\
- & \text { The study plan card ratification }\end{array}$ & $\begin{array}{l}\text { Fairly Good } \\
\text { Fairly Good } \\
\text { Fairly Good } \\
\text { Fairly Good }\end{array}$ & $\begin{array}{l}\text { Fairly Good } \\
\text { Fairly Good } \\
\text { Fairly Good } \\
\text { Fairly Good }\end{array}$ & $\begin{array}{l}\text { Fairly Good } \\
\text { Fairly Good } \\
\text { Fairly Good } \\
\text { Fairly Good }\end{array}$ & $\begin{array}{l}\text { Fairly Good } \\
\text { Fairly Good } \\
\text { Fairly Good } \\
\text { Fairly Good }\end{array}$ \\
\hline \begin{tabular}{ll}
\multicolumn{2}{l}{ Class and Exam } \\
- & Course schedule information \\
- & Spatial (Room) Information \\
- & Main exam schedule \\
- & Class replacement schedule \\
- & Grade Information \\
- & Delays of lecture information \\
- & The cancellation of lectures information
\end{tabular} & $\begin{array}{l}\begin{array}{l}\text { Fairly Good Fairly } \\
\text { Good }\end{array} \\
\text { Fairly Good } \\
\text { Fairly Good } \\
\text { Fairly Good }\end{array}$ & $\begin{array}{l}\text { Fairly Good } \\
\text { Fairly Good } \\
\text { Fairly Good } \\
\text { Fairly Good } \\
\text { Fairly Good }\end{array}$ & $\begin{array}{l}\text { Fairly Good } \\
\text { Fairly Good } \\
\text { Fairly Good } \\
\text { Fairly Good } \\
\text { Fairly Good }\end{array}$ & $\begin{array}{l}\text { Fairly Good } \\
\text { Fairly Good } \\
\text { Fairly Good } \\
\text { Fairly Good } \\
\text { Fairly Good }\end{array}$ \\
\hline & $\begin{array}{l}\text { Fairly Good } \\
\text { Fairly Good } \\
\text { Fairly Good }\end{array}$ & $\begin{array}{l}\text { Fairly Good } \\
\text { Fairly Good } \\
\text { Fairly Good }\end{array}$ & $\begin{array}{l}\text { Fairly Good } \\
\text { Fairly Good } \\
\text { Fairly Good }\end{array}$ & $\begin{array}{l}\text { Fairly Good } \\
\text { Fairly Good } \\
\text { Fairly Good }\end{array}$ \\
\hline \begin{tabular}{ll}
\multicolumn{2}{l}{ Contact service delivery } \\
- & Face-to-face services \\
- & Receiving a phone call \\
- & Receiving complaints \\
- & Asked for an explanation \\
- & Emerged to make mistakes
\end{tabular} & $\begin{array}{c}\text { Dissatisfactory } \\
\text { Dissatisfactory } \\
\text { Fairly Good } \\
\text { Dissatisfactory } \\
\text { Fairly Good } \\
\text { Dissatisfactory }\end{array}$ & $\begin{array}{l}\text { Dissatisfactory } \\
\text { Fairly Good } \\
\text { Fairly Good } \\
\text { Dissatisfactory } \\
\text { Dissatisfactory } \\
\text { Dissatisfactory }\end{array}$ & $\begin{array}{c}\text { Dissatisfactory } \\
\text { Dissatisfactory } \\
\text { Fairly Good } \\
\text { Dissatisfactory } \\
\text { Fairly Good } \\
\text { Dissatisfactory }\end{array}$ & $\begin{array}{l}\text { Dissatisfactory } \\
\text { Fairly Good } \\
\text { Fairly Good } \\
\text { Dissatisfactory } \\
\text { Dissatisfactory } \\
\text { Dissatisfactory }\end{array}$ \\
\hline
\end{tabular}

Based on Table 1 it can be seen that the general conditions of service encounter in college at the level was satisfactory. However there is still quite a lot that is at an unsatisfactory level, especially in the contact process at the time of service carried out. Both in public and private universities there are things that are not satisfactory in the service encounter. 


\section{Level of Service Quality}

Based on the results of the study, the conditions of service quality in providing services can be seen in Table 2 .

\begin{tabular}{|c|c|c|c|c|}
\hline \multirow{2}{*}{ Aspect } & \multicolumn{3}{|c|}{ Service Quality Category } & \multirow[b]{2}{*}{$\begin{array}{c}\text { Non-Accredited } \\
\text { Private Universities }\end{array}$} \\
\hline & $\begin{array}{l}\text { State University } \\
\text { Owned Legal } \\
\text { Entity }\end{array}$ & $\begin{array}{c}\text { State University } \\
\text { Non-Owned Legal } \\
\text { Entity }\end{array}$ & $\begin{array}{c}\text { Accredited Private } \\
\text { Universities }\end{array}$ & \\
\hline $\begin{array}{cl}\text { Tangibility } \\
\text { - } & \text { Administrative personnel apparel. } \\
\text { - } & \text { Administrative personnel appearance. } \\
\text { - } & \text { The working tools used. } \\
\text { - } & \text { Administration services space. }\end{array}$ & $\begin{array}{l}\text { Fairly Good } \\
\text { Fairly Good } \\
\text { Fairly Good } \\
\text { Fairly Good } \\
\text { Fairly Good }\end{array}$ & $\begin{array}{l}\text { Extremely Good } \\
\text { Extremely Good } \\
\text { Extremely Good } \\
\text { Extremely Good } \\
\text { Extremely Good }\end{array}$ & $\begin{array}{l}\text { Dissatisfactory } \\
\text { Dissatisfactory } \\
\text { Fairly Good } \\
\text { Dissatisfactory } \\
\text { Fairly Good }\end{array}$ & $\begin{array}{l}\text { Dissatisfactory } \\
\text { Dissatisfactory } \\
\text { Fairly Good } \\
\text { Fairly Good } \\
\text { Fairly Good }\end{array}$ \\
\hline $\begin{array}{l}\text { Responsibility \&Empathy } \\
\text { - } \quad \text { The responsibility of task completion } \\
\text { - } \quad \text { Problem solving Assistance }\end{array}$ & $\begin{array}{l}\text { Fairly Good } \\
\text { Fairly Good } \\
\text { Fairly Good } \\
\end{array}$ & $\begin{array}{l}\text { Fairly Good } \\
\text { Fairly Good } \\
\text { Fairly Good } \\
\end{array}$ & $\begin{array}{l}\text { Fairly Good } \\
\text { Fairly Good } \\
\text { Fairly Good } \\
\end{array}$ & $\begin{array}{l}\text { Fairly Good } \\
\text { Fairly Good } \\
\text { Fairly Good } \\
\end{array}$ \\
\hline $\begin{array}{ll}\text { Responsiveness } \\
\text { - } & \text { Response to the complaint } \\
\text { - } & \text { Response to the problem } \\
\text { - } & \text { Response to criticism \& suggestions }\end{array}$ & $\begin{array}{l}\text { Fairly Good } \\
\text { Fairly Good } \\
\text { Fairly Good } \\
\text { Fairly Good }\end{array}$ & $\begin{array}{l}\text { Fairly Good } \\
\text { Fairly Good } \\
\text { Fairly Good } \\
\text { Fairly Good }\end{array}$ & $\begin{array}{l}\text { Fairly Good } \\
\text { Fairly Good } \\
\text { Dissatisfactory } \\
\text { Dissatisfactory }\end{array}$ & $\begin{array}{l}\text { Fairly Good } \\
\text { Fairly Good } \\
\text { Fairly Good } \\
\text { Fairly Good }\end{array}$ \\
\hline $\begin{array}{ll}\text { Accuracy } \\
\text { - } \quad \text { Information Accuracy } \\
\text { - } \quad \text { Service Accuracy } \\
\text { - } & \text { Problem Solving Accuracy }\end{array}$ & $\begin{array}{l}\text { Fairly Good } \\
\text { Fairly Good } \\
\text { Fairly Good } \\
\text { Fairly Good }\end{array}$ & $\begin{array}{l}\text { Fairly Good } \\
\text { Fairly Good } \\
\text { Fairly Good } \\
\text { Fairly Good }\end{array}$ & $\begin{array}{l}\text { Dissatisfactory } \\
\text { Dissatisfactory } \\
\text { Dissatisfactory } \\
\text { Dissatisfactory }\end{array}$ & $\begin{array}{l}\text { Fairly Good } \\
\text { Dissatisfactory } \\
\text { Fairly Good } \\
\text { Fairly Good }\end{array}$ \\
\hline
\end{tabular}

Based on Table 2 it can be seen that the general conditions of service quality in higher education at the level was satisfactory. However there is still quite a lot that is at an unsatisfactory level. The condition is most common are in private colleges accredited and not yet accredited.

\section{Service Recovery Effort Program}

The results of the study on the Universities Service Recovery Effort condition to improve the failures of services performed can be seen in Table 3:

Table. 3 Service Recovery Effort Condition (SRE)

\begin{tabular}{|l|l|l|l|l|}
\hline \multirow{2}{*}{ Aspect } & \multicolumn{3}{|c|}{ Service Quality Category } & \\
\cline { 2 - 5 } & $\begin{array}{c}\text { State University } \\
\text { Owned Legal } \\
\text { Entity }\end{array}$ & $\begin{array}{c}\text { State University } \\
\text { Non-Owned Legal } \\
\text { Entity }\end{array}$ & $\begin{array}{c}\text { Accredited Private } \\
\text { Universities }\end{array}$ & $\begin{array}{c}\text { Non-Accredited } \\
\text { Private } \\
\text { Universities }\end{array}$ \\
\hline $\begin{array}{l}\text { - Provide an explanation when } \\
\text { things go wrong }\end{array}$ & Dissatisfactory & Dissatisfactory & Poor & Poor \\
$\begin{array}{l}\text { - Schedule replacement in the } \\
\text { event of lectures cancellation } \\
\text { - Cost replacement should there } \\
\begin{array}{l}\text { were losses due to the service } \\
\text { delays }\end{array}\end{array}$ & Dissatisfactory & Dissatisfactory & Fairly Good & Dissatisfactory \\
\hline $\begin{array}{l}\text { Service Recovery Effort } \\
\text { Condition }\end{array}$ & Dissatisfactory & Poor & Dissatisfactory & Dissatisfactory \\
\hline
\end{tabular}


Based on Table 3 it can be seen that in general that the service recovery efforts undertaken by all universities in general are still not adequate, that there are still many unsatisfactory or even worse.
This variable expresses on the students' feel or desire to move as a result of the administrative services they experienced. Based on the results of this study, the students' efforts or desire to move can be seen in Table 4.

\section{Students Switching Intention Condition}

Table. 4.Switching Intention (SI)

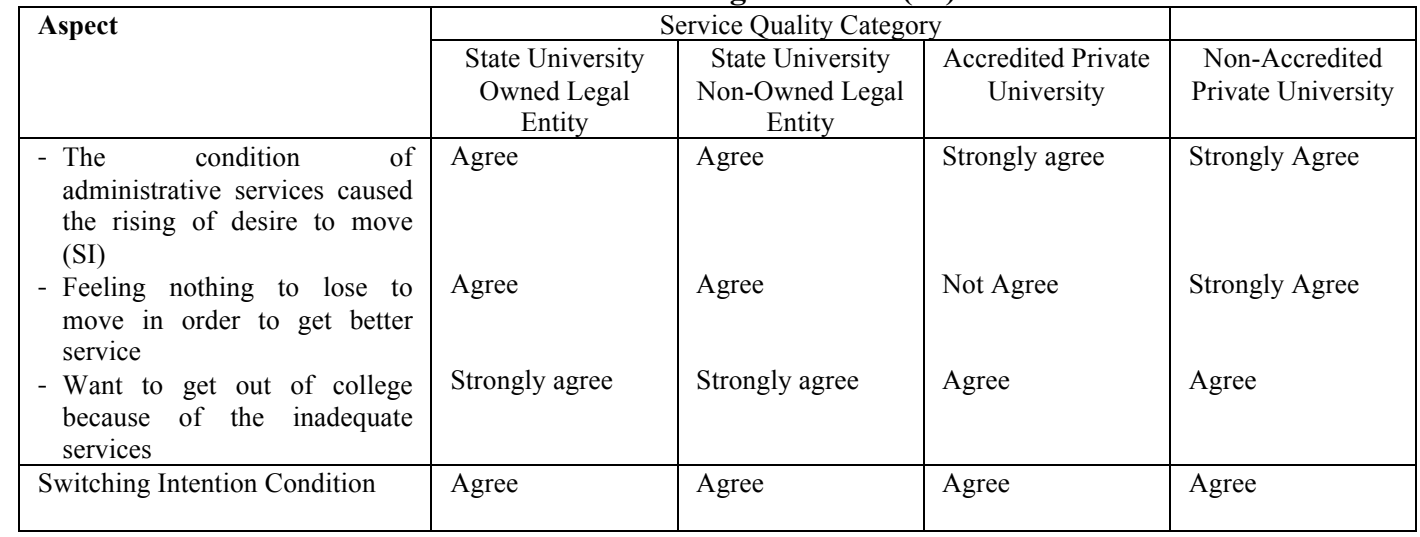

Based on Table 4 it can be seen that in general the intention to move after obtaining unsatisfactory services is quite high, it mean that students tend to move if obtaining unsatisfactory service.

\section{Hypothesis Testing Results}

Evaluation made by the students would be referring to the service quality description. As explained, the delivery of services involves several stages or processes ([9]. As previously explained that the failure of the service encounter stage can cause significant costs such as repeating jobs, compensation, loss of customers and negative word of mouth [10]. However, other studies showed that the explanation of the mistakes made by the service providers could ease the disappointment of the failure of services provision [11] [12] [13]. At this stage it is very important the role of frontline employee to provide services directly to customers (students) and for the success of the service encounter process [2] [4].

The attempts to compensate, giving an explanation to consumers about the failure of service delivery were efforts being made to improve consumers' evaluation of the services they received. Service recovery refers to the number of actions taken by the organization to respond to the failure of services [1]. The service failure occurs because of four things: (a) the promised services were not available, (b) the services rendered slow, (c) the results were inaccurate and (d) the employee was rude or uncaring. The explanation or repair provided by the service providers could be able to foster the perception of fairness for consumers [14] [15]. Perceptions formed were expected to foster a sense of comfort and reduce the desire to move. Thus it can be assumed that service recovery efforts undertaken by the service providers can affect the relationship between the service encounter effectiveness and service quality.

In other words, should there was a failure in the service encounter and a bad evaluation on service quality, service recovery efforts should be done so it could hamper the desire to make the switching intention.

\section{CONCLUSION AND RECOMMENDATION}

In general, the administrative services at four types of universities, namely the State University of Non-Owned Legal Entity, State Universities Owned Legal Entity, Accredited and Non-Accredited Private Universities showed no significant difference. The performance of service delivery in all four types of universities shown quite good range, especially in the aspect of new admissions selection, college preparation, lectures and exams. An important finding of this study was those universities have not shown the optimal performance of the services delivery, especially in the aspect of administrative employees' service attitude. In general, the attitude of the frontline employees by the time of doing contact was still far from adequate.

Regarding to the service recovery effort, in general those universities have done the optimization of service improvements yet. It could be shown in the results of service recovery effort; in which likely to be dissatisfactory on the whole group of universities. However, if it was associated with the switching intention, then it revealed that only a few conditions caused them in wanting to move out from the campus. Further we need to identify the phenomena based on technological approach in service encounter or service recovery.

\section{REFERENCES}

[1] Zeithaml, Valerie A. dan Mary Jo Bitner. 2000. Services Marketing; Integrating Customer Focus Accros the Firm.

[2] Lovelock, Christopher and John Wirtz. 2004. Service Marketing: People, Technology and Strategy. Pearson. Prentice Hall.

[3] Davis, Mark M dan Janelle Heineke. 2003. Managing Services; Using Technology to Create Value. Mc Graw Hill. 
[4] Groonroos, C. 2001, "The perceived service quality concept - a mistake?", Managing Service Quality, Vol. 11 No. 3, pp. 150-2.

[5] Sirdesmukh, Deepak; Singh, Jagdip; Sabol; Barry. 2002. Journal of Marketing; Jan 2002; 66, 1; ABI/INFORM Complete pg. 15

[6] Lovelock, Christopher., Wirtz, Jochen. Tat Keh, Hean. Lu, Xiongwen. 2005. Services Marketing in Asia; People, Technology and Strategy. Pearson: Prentice Hall.

[7] Harris, Llyod C and Emmanuel Ogbonna, 2002. Exploring Service Sabotage: The Antecedent ,Types and Consequences of Frontline, Deviant, Antiservice Behavior, Journal of Service Research, Vo. 4 No, 3.

[8] Harris, Llyod C and Emmanuel Ogbonna. 2006. Service Sabotage; $A$ Study of Antecedents and Consequences, Journal of The Academy of Marketing Science, Vo. 34 No. 4

[9] Verhoef, Peter C. et al. 2009. Journal of Retailing 85 Volume 1 p 31-41

[10] Bitner, Mary Jo., Bernad H. Booms and Lois A. Mohr. 1994 Critical Service Encounters: The Employee View Point. Journal of Marketing. Vol 58 No. 4

[11] Goodwin C, Ross I. 1992. Consumer responses to service failures: influence of procedural and interactional fairness perceptions. Journal of Bussiness Research Vol 25:149-63

[12] Gordon, H.G., Mc Dougal; Terrence Levesque, "Customer satisfaction with services: putting perceived value into the equation", Journal of Services Marketing, Vol. 14 Iss: 5, pp.392-410

[13] Mattila, Anna S. 2006. The Power of Explanation in Mitigating the IllEffects of Service Failure. Journal of Service Marketing. 20/7.

[14] Daskalopoulou, Irene. 2008. Fairness perceptions and observed consumer behavior: Results of a partial observability model. The Journal of Socio-Economics. Volume 37, Issue 1, February 2008, Pages 31-44

[15] Seiders, Kathleen and Berry, Leonard L.1998. Service Fairness: What It Is and Why It Matters. The Academy of Management Executive (19932005) Vol. 12, No. 2 (May, 1998), pp. 8-20 